\title{
Displacing informality: rights and legitimacy in Belo Horizonte, Brazil
}

\section{Introduction}

Aparecida is a poor black woman, who is over 50 years old. ${ }^{1}$ She is part of the group of informal workers - the "Mineirão stallholders" - that used to work in the surroundings of Mineirão, Belo Horizonte's main football stadium, until it closed its doors for modernisation works in 2010 envisioning the World Cup. She lives in a small favela in the North region of Belo Horizonte. The land where the settlement is located belongs to a private company and she is facing eviction from her small barraco (shack). The location has been chosen by the city hall to be site to Belo Horizonte's new coach station. She is not sure of what will happen in the future and narrated that, initially, the government wanted them out with no compensation but now, after a group of activists and the public defenders intervened, she is positive she is going to get something back, either in the form of cash or residence (an apartment). During the interview, she compared the experiences of being displaced from her house and from her working space: "I compare here and there, in the Mineirão, [it is] like here, right? Those who spent a lot of time [there]... we had that thing arranged, [we were] working with that for a long time... [so] it became almost like our home. I compare [the Mineirão] with the situation here, it is just the same."2 She is legally entitled to compensation for her home being taken from her, but what about the displacement she suffered from her workspace? If both places were like "home" to her, why aren't her rights equally recognised?

Accessing urban space for labour can be vital to those struggling for a place in the city but, unlike the right to housing, discussions about the right to work have been largely disassociated from space (Brown 2015; Schindler 2014). This paper is thus concerned with this gap in the literature and asks the following question: considering that the right to work and the right to housing

\footnotetext{
${ }^{1}$ In order to protect the identity of interviewees, all names have been anonymised.

${ }^{2}$ Interviews were conducted in Portuguese. All the extracts transcribed were translated by the author.
} 
are both enshrined in the Brazilian Constitution, why do claims upon space based on those constitutional rights hold distinct levels of legitimacy?

By addressing the above question, this paper will engage with current post-colonial debates in urban informality (Roy 2005). I argue that informality is a process which is affected by multiple state and non-state actors (Hackenbroch 2011; Schindler 2014). Moreover, I concur with views of the state as a processual and porous entity (T. Mitchell 2006; Painter 2006) that not only affects the production of informality, as argued by Roy (2005), but it is itself also affected by informal processes. I thus show how the urban informality framework can shed some new light on the debate about urban space production in Brazil. Moreover, I explore how discussions about urban informality, which have mainly focused in South East Asian and African contexts (Varley 2013), can benefit from incorporating the realities of Latin American cities. Such an endeavour can broaden the scope of the urban informality approach, aiding to the task of theorising from the South (Robinson 2006; Watson 2009). I intend to contribute by tackling two points that have been absent from these debates. First, I compare two ways of informally occupying urban space, for work and housing, revealing the distinct degrees of legitimacy embedded in such practices due to pre-existing institutional arrangements. Second, I emphasise the connection between work and home through the life strategies and place-making practices of the urban poor.

In Brazil, "illegal" occupation of land for housing purposes has been partially recognised through the City Statute, a federal law approved in 2001 that regulates the right to housing and the social function of urban property (Fernandes 2012). Many have discussed the role of the working classes in the process of building cities from scratch (Fischer, McCann, and Auyero 2014) through the practice of autoconstruction in the peripheries (Maricato 1979; Holston 1991) which Caldeira (2016) has recently labelled "peripheral urbanisation". The movement of insurgent citizens emerging from these autoconstructed peripheries, claiming the right to the city they have built, was paramount to the development of progressive legislations and institutions (Holston 2008). Nonetheless, both the academic literature and the institutional development have been focusing 
only on the informal occupation of space for housing purposes. In this paper, I contrast the former with another way of building urban space through the occupation of land for urban livelihoods (Brown 2015). Through this comparison, I intend to show how the struggles of the urban poor involve distinct informal practices that are not equally legitimised. In Brazil, the way that peripheral urbanisation evolved has partially shaped the state, explaining the differential legitimacy enjoyed by distinct informal practices. Nevertheless, those practices are connected through the survival strategies of marginalised populations and thus essential for their urban belonging. Ultimately, that shows how the constitutional rights to work and housing are interrelated and how their fulfilment is depended upon access to urban space.

To achieve those aims, I analyse qualitative data regarding two cases of displacement in the Brazilian city of Belo Horizonte, both connected to the hosting of the 2014 Football World Cup. The data was gathered during five months of fieldwork between July and December 2015 . The first case focuses on a group of approximately 150 families of informal workers known as "The Mineirão Stallholders", displaced from their workspace due to the modernisation of the local football stadium. The second case concerns an informal settlement, the "Vila Recanto UFMG", from where 90 families were evicted and relocated due to a viaduct project, designed to improve public access to the football stadium.

The rest of this paper is divided into four parts. Section two presents some of the recent debates in urban informality and the theoretical framework for this paper. Sections three and four present the case studies, discussing the findings from qualitative research (interviews, field notes, and archival documents). Section three discusses their displacement and their struggle for appropriate compensation. The fourth section focuses on the stallholders' case, emphasizing the connection between informal spaces; the workspace and the home. Finally, the last section concludes with a discussion about the findings in light of the theory on informality.

\section{Informality in the context of peripheral urbanisation}




\subsection{Towards a relational approach to urban informality}

Recent developments in postcolonial urban theory have called for an understanding of informality as a mode of urbanisation, rejecting the standard dichotomy of the formal and the informal as two separate sectors (Roy and AlSayyad 2004; Roy 2005; Watson 2009). In this perspective, the state plays "an active role in shaping fluid formal-informal relationships, rather than being absent or a weak background factor (te Lintelo 2017, 77)”. Informality is thus regarded not as the exception to planning, or what lies outside the realm of planners' control, but rather as something produced by the state. The latter is described as the "sovereign" that sits both outside the law and has the monopoly over it (Agamben 1998). Therefore, the "exception", or the temporary suspension of the law, is enacted by the state apparatus to (de)legitimise according to the interests at play.

In this context, some forms of informality commonly found in places such as skyscrapers and gated communities are not only permitted but even encouraged, seen as desired urban forms in consonance with the world-class city aesthetics (Ghertner 2015). Others, such as informal settlements, are perceived as threats to capital accumulation and, therefore, are prone to constant threats of displacement. For Roy (2005) the distinct legitimacy enjoyed by different forms of informality can be perceived as a direct outcome of the state's action through its planning and legal apparatuses. In her approach, the state is perceived as the holder of the power "to determine what is informal and what is not, and to determine which forms of informality will thrive and which will disappear" (Roy 2005, 149). According to this perspective, (in)formality thus emerges through the process by which the state draws the line between what is inside and outside the rule of law.

For the Brazilian case, Telles (2010) proposes a very similar framework. Her work explores the interstices between informal, illegal and illicit practices in urban spaces of São Paulo, focusing on the power dynamics and negotiations governing the everyday life of the "globalised modern city". She argues that: 
[In] its most violent forms, it is not properly about a legal-illegal porosity, neither it is about uncertain frontiers between the informal, the illegal, the illicit. It is rather about the suspension of such frontiers to the extent that the difference between the law and its transgression is nullified. (Telles 2010,117) [Translated by the author]

Such situations characterise what Agamben (1998) has called the states of exception through which some bodies, classified as "delinquents", are turned into the homo sacer, ${ }^{3}$ whose execution is "authorised" by the suspension of the law. Therefore, Telles (2010) reaches a similar conclusion to the one proposed by Roy (2005) in which informality (illegality) operates as a mode of governance. ${ }^{4}$ From her perspective, illegality is not a straightforward category, but rather a tool for the management of bodies that expose "the way in which state sovereignty is affected through the power of suspending its own law" (Telles 2010, 218).

Empirical research engaging with urban informality has focused on how (in)formality emerges as an outcome of never-ending negotiations and struggles among various actors (Schindler 2014; Hackenbroch 2011; Crossa 2016; Kudva 2009). What is interesting about such perspectives is that they challenge the idea that legitimacy is something that emanates uniquely from the state and its apparatus as it is assumed in Roy's (2005) approach. Research has revealed that other agents, such as the middle-classes can play an important role in legitimising informal practices (Schindler 2016). Others, like Crossa (2016), have argued that although the formal/informal split is deployed by the state as a strategic narrative to justify displacement, "it is not only the state who actively participates in the construction of this narrative, but so-called informal people themselves by enacting the formal/informal divide in contexts of displacement and exclusion" (ibid, p.300).

\footnotetext{
${ }^{3}$ The homo sacer represents bare life, and it is a term borrowed from the Roman period, meaning sacred man or living dead. It is used in relation to "life that can be killed with impunity, but not sacrificed" (K. Mitchell 2006, 96). The homo sacer constitutes, therefore, an exception to the divine law - because it cannot be sacrificed - and to juridical law - because it can be killed without punishment.

${ }^{4}$ Despite the similarities, in the work of Telles (2010) violence emerges as central regulatory practice. That is understandable considering its relevance in the Brazilian context.
} 
Analysing the case of street hawkers struggling against displacement in Dellhi, Schindler (2014) explored the struggles and negotiations performed by state and non-state actors, showing how the boundaries of formal/informal constantly shifted in this process. He concludes that:

(...) power is dispersed across a range of sites, and rests in varying degrees with a host of state and non-state actors, none of whom are able to unilaterally impose their preferred vision of formality. Instead, these interest groups negotiate and struggle to define (in)formality and gain control over, or access to, urban space. (Schindler 2014, 2597)

Also looking at Delhi, te Lintelo $(2017,78)$ uses the concept of "public authority" to show how "state fragmentation; informal practices by the state; and horizontal contestations within society and within the state" are key aspects contributing to the (re)production of informality. Hackenbroch (2011) presents a similar analysis for the case of Dhaka, examining the negotiation process that determines the rules of access to public space. Drawing on Lefebvre's (1991) and Soja's (1998) contributions, she argues that statutory (formal, regulated) and informal spheres do not represent the poles of a binary relationship but rather interlock in a complex process of negotiation. Every space should, thus, be understood as negotiated and ever-shifting due to the changing nature of power structures. Therefore, claims over space are dependent upon the capacity of different agents to legitimise them, which relates to their access to power and power relations.

In tandem, these discussions point to the need for looking beyond "studies that 'vertically" juxtapose state and society" (te Lintelo 2017, 78) to produce careful examinations of the uneven distribution of power among the varying range of actors engaging in urban governance. In this paper, I argue that the state is not the only institution able to convey legitimacy to informal practices. The state is regarded as "a part of wider constellation of institutions and actors" (ibid) participating in urban governance. I thus follow Roy's (2005) call for the abandonment of rigid separations between formal and informal, but seek to expand her framework by focusing on the formation and transgression of those boundaries, which involve multiple state and non-state agents. Moreover, I propose an approach inspired by Massey's (2005) concept of relational space, which 
has two main implications for the understanding of informality. Firstly, I foreground the spatial and relational characters of distinct informal practices, emphasising their connection through the life strategies of the urban poor. This point has been explored by Kudva (2009), who discussed the mutually constitutive political and spatial practices of informality in her study of India. She argues that switching the focus to space allows a holistic approach that emphasises, for instance, the integration between distinct informal practices. A similar argument has been made by Lagos (2011) whose analyses of the lives of precarious workers in the peripheries of Rio de Janeiro, points towards the need for understanding the complex relations between places of work and the home; moving beyond bounded understandings of the fields of economic production and social reproduction. Secondly, I adopt a nuanced view of the state that highlights the blurriness of statesociety relations (Painter 2006). I thus explore how informal practices may also affect the state, revealing how urban space and the state are mutually constituted processes. Such discussion will be contextualised in relation to the process of peripheral urbanisation in Brazil which I analyse in the next section, with attention to how the state has been modified by the struggles of insurgent citizens (Holston 2008).

\subsection{Informal urban space production and institutional change in Brazil}

It has been argued that the social production of urban space in Brazil is increasingly promoted through informal processes (Fernandes 2007). Caldeira (2016), has named "peripheral urbanisation" the process through which residents informally build their own houses and neighbourhoods, becoming themselves agents of urbanisation. In this account, residents are not passive consumers of space, regulated by others, but are building cities themselves from scratch (Fischer, McCann, and Auyero 2014). In doing so, these citizens "also propose a city with a 
different order of citizenship" (Holston 2009, 246). For Holston (2009) the entanglement of urbanisation and democracy has produced the "insurgent citizenship" phenomenon, that is, a crowd of marginalised citizens that contest their exclusion, claiming the rights to the city they have built.

During the 1980s, the re-democratisation process in Brazil opened a new window for popular participation (Caldeira and Holston 2015). In 1987, the National Constituent Assembly was formed, drawing the country's new democratic constitution. The possibility of submitting popular amendments has involved several societal sectors in this process. That was the case of the Urban Reform Proposal, drafted by urban popular movements from different regions of the country (Costa 1989; Ermínia Maricato 1988). As a direct result of such mobilisations, the 1988 Constitution included a chapter dedicated to Urban Policy (Fernandes 1995).

The City Statute, which came into effect as a federal law in 2001, regulates the original constitutional chapter on urban policy. It was the result of more than ten years of discussion "within and beyond the National Congress" (Fernandes, 2007, 212). The legislation, considered very progressive, explicitly recognises the "right to the city" (Lefebvre 1968) as a collective right, which was a major change in the "long-standing, individualistic tradition of civil law" (Fernandes 2007, 212). However, the debates surrounding the City Statute were also influenced by the emergent neoliberal urban paradigm. As a result, some of its instruments ${ }^{5}$ have been co-opted by urban "growth machines" (Rolnik 2013; Molotch 1976). Despite all the critiques, it is undeniable that the City Statute made progress in meeting the demands of the urban reform agenda, which was mainly focused on guaranteeing the right to participation in the planning process and access to secure land tenure.

\footnotetext{
${ }^{5}$ For instance, the "urban operations consortium" (UOC) is an instrument that, although potentially redistributive, has been used to fuel real estate speculation. The City Statute establishes the possibility of the government issuing bonds in the form of Certificates of Additional Construction Potential (CEPAC) to fund UOCs. The CEPACs are bonds that give their holder the right to build above permitted limits. The advantage for the government is the possibility of collecting resources in advance. However, recent experiences have shown that in practice they engender financialisation and real estate speculation (Sánchez and Broudehoux 2013; Ermínia Maricato and Ferreira 2002).
} 
Research focusing on the landless workers movement in Brazil have shown how social movements have learned how to employ strategies that explore the contradictory nature of the Brazilian law as far as land is concerned: "This involves not only making use of the legal tools available, but also the construction of alternative interpretations of the law in an attempt to generate jurisprudential solutions that are favourable to the struggle for land and social justice" (de Sousa Santos and Carlet, 2009, p.69). That also reveals how informal spaces are not unregulated voids and informal practices are also conditioned by the state law (Chiodelli 2016; Rosa 2017; Boamah and Walker 2017). According to Varley (2013), moving beyond the binary understanding of formal/informal requires not only recognising that informality is present in elite spaces, but also that the law is present in informal spaces. The practices of those inhabiting informal spaces, she argues, are shaped by their perceptions of the law. A similar argument is developed by Chiodelli and Moroni (2014), who contend that unauthorised settlements do not exist outside the law, but are rather influenced by it. Their approach rejects the compliance/non-compliance binary as the only possible reaction to the law. They argue, instead, for a broader understanding that also considers unintentional effects of legislations, that is, actions that do not adhere to the prescriptions of the rules but somehow take them into account.

In this paper, I explore how informal spaces produce new interpretations of the law that might, in some circumstances, later become institutionalised state practices. For the Brazilian case, the legal developments that culminated with the City Statue approval reveal how urban space production and the state are mutually constituted processes. The implementation of this new legal apparatus thus represents both the result of accumulated struggles of the past and a new arena for contestation. This institutional environment enables social movements for housing and informal settlements facing displacement to legally contest evictions or, when those take place, to at least negotiate and guarantee legally entitled compensations.

However, despite such advancements, the theoretical debates and legal developments mentioned above have been solely focused on the production of urban space for housing. While a 
growing share of population takes part in the so-called informal economy, not much has been written, in Brazil or globally, on the struggles of the marginalised urban poor's rights to secure workspace (Brown 2015). Although access to housing is unquestionably important, guaranteeing permanence in the city for many is also a matter of accessing workspace (Schindler 2014). Brown (2015) has noted that:

While the need for secure tenure for housing land has been widely recognized, land for urban livelihoods has received limited attention although the informal economy provides the majority of jobs in many developing country cities; meanwhile land in the public domain is excluded from land debates despite its central role in accommodating street vending and other urban work. (Brown 2015, 239)

In Brazil, like all Latin American countries, the weight of the informal economy is considerable and the debates regarding this phenomenon are almost as old as the urbanisation process itself. ${ }^{6}$ Nonetheless, many cities have strict rules against the activities of informal workers in urban space. ${ }^{7}$ Some scholars have analysed how street vendors are constantly threatened with forced eviction (Crossa 2009; Itikawa 2016; Schindler 2014). They have weak arrangements with the local states that do not guarantee any kind of social protection or secure access to space (Itikawa 2016). Street vendors, however, are also able to resist, challenging and subverting neoliberal entrepreneurial strategies aimed at supressing their presence in the urban environment (Crossa 2009). However, at least in the case of Brazil, their struggles have not yet been translated into greater social protection, which is still attached to formal forms of employment. ${ }^{8}$ Moreover, the right to work is not conceptualised in relation to space and the production of urban space through labour does not translate into rights to workspace. In this paper, I argue for the need of understanding the connections between working, housing and the city, showing how, for the urban

\footnotetext{
${ }^{6}$ In Brazil, according to the latest data available $51.1 \%$ of total non-agricultural employment is informal (OECD 2009).

${ }^{7}$ For a review on the subject see Bhowmik (2012).

${ }^{8}$ It is interesting to notice that both the housing movement and the labour movement are in the roots of the Worker's Party (PT) foundation. Lula, the Brazilian former president and most prominent politician from the PT has emerged from the movement of unionised workers in São Paulo.
} 
poor, guaranteeing access to the full entitlements of citizenship is often depended upon accessing urban space for multiple purposes.

In the next section, I explore how past struggles have shaped distinctively the institutional channels available for informal workers and informal residents to have their claims upon space validated. These topics are explored through the analyses of two "informal" groups displaced in the context of the preparation for the 2014 Football World Cup. I am interested in how the urban poor's claims upon space are affected by spatial restructuring. Mega-events as moments of intense urban change, in which "growth machine" (Molotch 1976) alliances are at full operation, provide interesting lenses to interrogate issues of social justice. In both cases, citizens claim their rights through the occupation and production of urban space. Nonetheless, once displaced, their ability to be compensated/relocated by the state are distinct, shaped by historically embedded relationships. Such arrangements influence how struggles unravel and which claims are legitimised.

\section{Displacing informality: mega-events, spatial restructuring and the urban poor}

\subsection{Displacing work informality: the case of the Mineirão stallholders}

Belo Horizonte’s main football stadium, "Estádio Governador Magalhães Pinto”, popularly known as "Mineirão", was founded in 1965 and was managed by the state of Minas Gerais until 2010, when it was closed for renovation envisioning the 2014 Football World Cup. The modernisation was completed through a public-private partnership (PPP) between the state and Minas Arena. ${ }^{9}$ The latter was to be responsible for managing the new multipurpose arena until 2037. The total cost of renovation was $\mathrm{R} \$ 666.30$ million ( $£ 212.96$ million): of this, $\mathrm{R} \$ 400.00$

\footnotetext{
9 Minas Arena consortium is formed by "HAP - Engenharia LTDA", "EGESA Engeharia S/A" and "CONSTRUCAP - CCPS Engenharia e Comércio S/A". Various irregularities have been pointed in the PPP contract signed. During two years there were political negotiations for the opening of a parliamentary inquiry in the state assembly, but they were not successful.
} 
million ( $£ 127.84$ million) was funded by the Brazilian Development Bank (BNDES) through a special subsidised credit line created exclusively for funding the construction/renovation of the 12 World Cup host stadiums. ${ }^{10}$ The modernisation of Mineirão followed the same trend described by Gaffney (2010) for the case of Maracanã in Rio de Janeiro. That is, it entailed the reduction of overall capacity, especially by eliminating popular seats (the "geral" ${ }^{11}$ ). The new stadium caters for supporters with higher disposable income and symbolises the exclusionary character of the world-class aesthetics associated with mega-events (Shin 2012; Shin and Li 2013; Ghertner 2015).

Before the renovation, the stadium was surrounded by an open space and, during match days, several informal street vendors would sell food and beverages for football fans. When the stadium was closed in 2010, this informal local economy was dismantled and, after the stadium was re-opened in 2013 , the $80,000 \mathrm{~m}^{2}$ space became privatised and enclosed. In this process, a group of approximately 150 families that had historically occupied the space - some since its inauguration - were displaced. These workers, known as the "Mineirão stallholders", remained "informal" during the entire period of their activity. However, until before their displacement, they were able to claim the urban space for over 50 years through a process similar to what Bayat (2004) has described as the "quiet encroachment of the ordinary", defined as the "non-collective, but prolonged, direct action by individuals and families to acquire the basic necessities of life (land for shelter, urban collective consumption, informal work, business opportunities, and public space) in a quiet and unassuming, yet illegal, fashion" (ibid, 81). They enjoyed legitimacy that emanated from the culture embedded in that space and from a weak and non-confrontational relation with the state. Their presence was "institutionalised" through their constant negotiation with multiple state authorities, including the stadium managers, the local inspection agents and the police.

\footnotetext{
${ }^{10}$ Values in pounds calculated using the official exchange rate of February 3, $2013(£ 1.00 / \mathrm{R} \$ 3.13)$, the date of the stadium's re-inauguration.

${ }^{11}$ The "geral" was a section of the stands with low ticket prices and unreserved seats. According to Gaffney (2010, 13): "The geral was a low-lying area of concrete that encircled the field. This 'populist heart' of the stadium was a functional and symbolic space that allowed for the inclusion of all social sectors in public life because of the low ticket prices."
} 
After the stadium was closed for renovation, the stallholders were displaced without any plans for relocation. Although they did not fight against the displacement itself, they have been demanding their right to resume their activities in the stadium since 2010. In the stadium modernisation process, they were identified as a group affected in the environmental impact report required legally for large impact projects. ${ }^{12}$ From the stallholder's perspective, however, the mitigation initiative included in the PPP contract is inadequate: it only required the company to provide training in order to include them in the labour market, with no rights to compensation and/or relocation. ${ }^{13}$ Nevertheless, although the stadium was often crowded with informal traders, the stallholders were the one group recognised by the state, which points towards the complex scales involving informality within informality (Roy 2005) and to a politics of difference among informal traders (Crossa 2016).

The municipal law No 8,616 (2003), known as the Code of Placements (Código de Posturas), prohibits the activities of street vendors in public spaces without an appropriate license. The law has been deployed by the municipal government as a justification to deny the stallholders the right to relocation to streets near the stadium, while the PPP contract hinders their chances of resuming the activities in the same place as before. Therefore, in the absence of a clear "legal" basis for their demand, the stallholders have deployed many different strategies and discourses to legitimise their claim. Nonetheless, their efforts have proved unsuccessful and they have been "replaced" by a new group of licensed stallholders selected through a public bid launched by the local government at the end of 2015. The bid was open to all those interested, using the highest offer criteria to select the beneficiaries. In my interviews with local state officials, they have argued

\footnotetext{
${ }^{12}$ The renovation project was considered as a large impact project by the Municipal Secretary of Environment (DEOP-MG, Gustavo Pena and Práxis, 2010). In these cases, Belo Horizonte's municipal legislation requires a compulsory impact study, which is required for the issuing of the "environmental license" for construction. See Araújo (2009) for a discussion about environmental studies on urban spaces in the context of Belo Horizonte.

${ }^{13}$ The environment restriction n. 18 of the PPP contract says: "Forward periodic reports about the articulation actions for the inclusion of the traders that use the outside area of Mineirão in formation and training programs for the formal trade and/or fair trade." (Environmental City Council, 2010)
} 
that they were not able to give the displaced stallholders an "advantage" as it would be unfair to other bidders potentially interested.

\subsection{Displacing house informality: the case of the Vila Recanto UFMG}

In January 2010, also following the announcement of Belo Horizonte as a host city for the FIFA event, a series of investments in the city's infrastructure were announced. Originally, eight interventions in urban mobility were foreseen, amounting to a total spending of $\mathrm{R} \$ 1.5$ billion ( $£ 530$ million). ${ }^{14}$ The project "BRT: Antonio Carlos/Pedro I" envisioned the enlargement of the avenues connecting the city centre to the airport, and the installation of a BRT system along their extension. The total investment of $\mathrm{R} \$ 688.2$ million ( $£ 242.47$ million) was divided between the municipal (44.4\%) and the federal governments (55.6\%), the latter using funding from CAIXA, a federal public bank. The large majority of the municipal resources - $\mathrm{R} \$ 300$ million ( $£ 105.70$ million) were designated to pay for land expropriation. One of the targeted areas was a piece of land located across the street from the Federal University of Minas Gerais (UFMG) where the City Hall intended to build a viaduct to improve the public access to the stadium. On this land, there was an ocupação ${ }^{15}$ known as "Vila Recanto UFMG" where 90 families were residing.

The Vila Recanto UFMG was an informal settlement formed in the mid-1990s by a group of squatters who occupied a vacant lot - 7070 Antônio Carlos Avenue - after a car shop declared bankruptcy and abandoned the building. The Pampulha region, where the settlement was located, is comprised of mostly middle-class neighbourhoods, and it is well-provided with infrastructure and access to services. In April 2010, the municipal decree No 13,955 listed the land where the Vila was located as the property of a private company - BH Imóveis - while also declaring the

\footnotetext{
${ }^{14}$ Values in pounds calculated using the official exchange rate of January 13, 2010 ( $\left.£ 1.00 / R \$ 2.84\right)$, the date in which the investments were announced.

${ }^{15}$ The term ocupação, which translates literally into occupation, will be used in this thesis as a synonym of informal settlement. This choice intends to highlight the political meaning of the term, which is used by social movements "to refer to an area of private or public land that does not fulfil its social function as property and is occupied by poor residents (mostly organized by militant housing movements)” (Nascimento 2016, 1).
} 
land expropriated for public utility reasons. In this process, the company was compensated by the ownership of the land and a new round of negotiations started regarding the displacement of the residents by the local government. Eventually, in 2011, all 90 families residing in the space were displaced.

Similar to the case of the informal stallholders, the residents of the Vila UFMG did not fight against displacement. At the beginning of the process, there was some suggestion to do so, but such view was eventually discouraged. Residents were then convinced to accept the compensation to which they were legally entitled. In Belo Horizonte, the Municipal Housing Policy (PMH), established in 1993 as a result of years of struggle by the housing movement, regulates displacement in informal settlements caused by public construction or environmental risk. ${ }^{16}$ The Urbanising Company of Belo Horizonte (URBEL) was the municipal institution in charge of managing the displacement of the occupation: according to municipal law they are the organisation responsible for handling eviction in the so-called "informal city". ${ }^{17}$ The URBEL's work with the residents lasted for roughly one year, from the first meeting in May 2010 until the demolition of the settlement in May 2011. In the end, all families received either cash or in-land compensation. The latter involved relocation to houses within Belo Horizonte's metropolitan region or to the social housing apartments provided - see Table 1 for a summary. The compensation was calculated considering only the value of the buildings and not the value of the land, as regulated by law. Those that opted for social housing were relocated to apartments on the borders between Santo André neighbourhood and one of Belo Horizonte's favelas, Pedreira Padre Lopes. The estate is located closer to the city centre and within $10 \mathrm{~km}$ from the original occupation site. Moreover, all those relocated to apartments live in the same building.

\footnotetext{
${ }^{16}$ For a discussion about the PMH in Belo Horizonte and the trajectory of the policy, see Bedê (2005).

${ }^{17}$ Another organ, SUDECAP, manages displacements in formal areas, that is, where residents own property titles.
} 
Table 1 - Summary of the Project: Works on Antônio Carlos and Abraão Caran Avenues

\section{intersection}

\begin{tabular}{|l|r|l|l|l|}
\hline Modality & Concluded & New Address & $\begin{array}{c}\text { Total } \\
\text { Expenditure with } \\
\text { Resettlement and } \\
\text { Compensations }\end{array}$ & $\begin{array}{c}\text { Average } \\
\text { compensation }\end{array}$ \\
\hline Social Housing & 28 & $\begin{array}{l}\text { "Vila Viva } \\
\text { Residential" at } \\
\text { Pedreira Padre } \\
\text { Lopes }\end{array}$ & - & \\
\hline Assisted Resettlement & 9 & Diverse & $\mathrm{R} \$ 1,874,849.45$ & $\mathrm{R} \$ 30,735.24$ \\
Cash compensation & 53 & \multicolumn{2}{|c|}{$(£ 713,440.21)^{*}$} & $(£ 11,695.74)^{*}$ \\
\hline
\end{tabular}

Source: URBEL

(*)Values in pounds calculated using the official exchange rate of May 1st, 2011 $(£ 1.00 / \mathrm{R} \$ 2.63)$, the approximate date in which compensations were paid.

Most of the residents that opted for cash compensation or assisted resettlement (PROAS) ${ }^{18}$ now live in the peripheries of the metropolitan region, as the in-cash compensation was inadequate for them to purchase a house in a location with similar conditions as those found at Pampulha. Regarding those that opted for apartments, some sold them and moved to houses in the peripheries, closer to family, or into other occupations. Those who remained in the social housing building are often unhappy about living in flats where they cannot grow anything or renovate the interior to accommodate family necessities. Many criticisms are pertinent regarding the displacement/resettlement process. One could discuss the peripheralisation of poverty, the denial of their legal rights to receive compensation also for the land (at least for the older residents) and

\footnotetext{
${ }^{18}$ PROAS is the municipal program for assisted resettlement that targets families evicted from informal houses due to public constructions or geological risk. Assisted families can choose a house located in non-risk areas within the metropolitan region of Belo Horizonte of up to $\mathrm{R} \$ 40,000$.
} 
their right to the city. However, municipal (and federal) law partially recognised their rights and no one left without some sort of compensation.

\subsection{Partial recognition of rights versus institutional void}

Previous struggles in the social movements for the right to housing have engendered the creation of institutions and laws that partly recognised the rights of informal residents such as those in Vila UFMG (Holston 2008; Rolnik 2013). On the other hand, the informal stallholders did not enjoy any rights to compensation and/or relocation. In Belo Horizonte, like many other places where informal housing is widespread, the movement for housing has succeeded, albeit partially, in modifying the state and creating mechanisms that encompass urban poor's rights to urban land for housing. Belo Horizonte was one of the first Brazilian cities to implement policies of favela upgrading. The PRO-FAVELA program, instituted by a 1983 municipal law ${ }^{19}$ (Fernandes 1995), allowed for partial recognition of the rights of favela dwellers to basic services. In 1986, the URBEL was created, in charge of the regularisation and the improvement of informal settlements. From 1993 onwards, eviction in informal settlements became regulated by the local law, and compensation schemes were established. In this context, however, displaced residents are often unable to fight for better compensations or for their right to stay put. Since the law describes the rightful compensation, affected populations must accept those conditions with no room for further negotiation.

In comparison, despite the centrality of the so-called informal economy for the surviving strategies of the urban poor, not much debate regarding their rights to workspace has been had, let alone any institutional development in this direction. The situation is quite the opposite. Following the creation of the municipal law that explicitly prohibits the activity of street vendors, the local government has often persecuted workers, apprehending their products and blocking their access

\footnotetext{
19 The Pro-favela program was instituted through the Municipal Law 3,532/1983, which benefited from the legal opening engendered by the Federal Law 6,766/1979 that regulated urban land division.
} 
to urban space. Moreover, the local government has recently made an effort to regulate all the existing local street markets, launching several public bids that, similarly to the Mineirão case, always apply the highest offer criteria to select the beneficiaries. This initiative has been highly criticised for promoting the higienização (hygienisation) of such spaces, excluding those in the most precarious situations, who are unable to compete.

Once displaced, therefore, the trajectory of the two groups analysed above are divergent. Spatial restructuring unevenly affects their abilities to claim their rights to access urban space. In most of the literature regarding the peripheral urbanisation (Caldeira 2016), the role of excluded citizens building the city through autoconstruction is emphasised, whereas the informal economy has been mostly analysed in a separate body of literature. Nevertheless, some authors (Kudva 2009; Schindler 2014; Lagos 2011) have been pointing out the importance of accessing urban space for informal workers struggling to guarantee their permanence in the city.

The comparison between the cases reveals not only how different informal spaces are treated differently by the state, but also how informal spaces can affect the state in varying manners. While the struggles of insurgent citizens created institutional channels for displaced informal residents to claim rights, the encroachment of informal street vendors on urban space has led to increasing criminalisation of their practice and no recognition of rights. I argue thus for a need to understand the informal economy beyond dualistic assumptions that have long dominated analyses of informality and the periphery in Latin America. This paper thus intends to emphasise the importance of accessing workspace for the fulfilment of citizenship, foregrounding the relations between spaces of work and the home. It is through the informal economy that a large number of workers from the periphery make a living. In the next section, I thus explore the connections between work and housing informality, focusing on the case of the Mineirão stallholders.

\section{Interrelations between access to workspace and urban belonging}

\subsection{Accessing workspace: making a living and making a home}


The Mineirão stadium was inaugurated in 1965 with the capacity for 130,000 spectators. At that moment, football stadia in Brazil were largely built by regional or federal states, with a clear political and populist objective. They were popular spaces, catering for the working classes and managed by the state. Since its inauguration, Mineirão was also characterised by the presence of informal street vendors in the stadium surroundings. This informal economy was as popular as the stadium itself, becoming a space for many disadvantaged workers looking for a place to make a living. In its early days, the situation was precarious, as narrated by Rodrigo who started working in the stadium in that period.

So, I started working as an employee with the popcorn cart. (..) [In that period] there were only popcorn carts around the Mineirão, there was nothing more. By the way, there was not even asphalt there yet. The first games there... it was all gravel, later that they [asphalted the surrounding area]. (Interview with Rodrigo, Mineirão stallholder $04 / 08 / 15)$

In the beginning, the occupation of the space was disorganised and the informal vendors would use improvised ways to prepare and commercialise the goods. Vilma also started working at Mineirão in this period. She and her siblings - all children - would accompany their mom and sell home-made ice-pops for the football fans. She narrated her recollections of those early days at the stadium:

When my mother started working at the Mineirão the stadium was already there, but the people there were selling what? Skewers made in cans (churrasco na lata), for instance, right? (...) We were very young still. We used to make a huge box [full of ice-pops], just like the one you saw outside [her house] and we took it there by bus. (Interview with Vilma, Mineirão stallholder - 04/08/15)

At that time, Vilma and her siblings were all living with her mom and their stepfather, whilst her mom worked in order to bring money to the household and raise her children with almost no help from her partner. The informal trading at the stadium thus became a source of income for the family. 
The first car my mother had was a beige Volkswagen (fusquinha). She bought the car with ice-pop money. Can you believe it? She saved all the coins, and saved all the icepop money, and then she bought a brand-new Volkswagen! (Interview with Vilma, Mineirão stallholder - 04/08/15)

The livelihood of Vilma's family was hence dependent on their work at the stadium. The income they were able to get from the sales was used to pay the bills and the rent. Her mother was uneducated, but she was able to raise all her children through her work at the stadium. The Mineirão was, therefore, a popular space where disadvantaged workers were able to make a living.

The case of Lucia exemplifies how being a stallholder at Mineirão allowed her family to guarantee not only their subsistence, but some degree of social mobility. Through her activity as a street vendor, Lucia was able to build her house and give her kids access to education, something she was only able to accomplish later in life. She particularly recalls a certain period in the mid2000s when the local clubs were attracting many supporters to the stadium, which had a positive impact on her income.

It was 2007,2006 , something like that. It was a very good period for everybody. (...) Then I started building this house that was only a shack before. I was living here with my three kids. (...) Then I called the mason, he made the budget for me and I said: "Now I'll knock down this thing". Then we stayed here and, in a little while, he built this. In a blink of an eye, I did this, two floors. Then I moved the bedroom to the upstairs and made this big living room. (Interview with Lucia, Mineirão stallholder $02 / 12 / 15)$

In the quote, Lucia explained that once she heard rumours about the closing of Mineirão, she decided to invest the stall's income into building her house. Her home is an example of the autoconstructed houses discussed in the peripheral urbanisation literature (Caldeira, 2016). Her story reveals how the practices of living and working informally are connected through the livelihood strategies of the urban poor (Kudva 2009) and how spaces of living and working are mutually constituted (Lago 2011). The informal residents of the peripheries often depend on their access to a workspace to build their houses and, consequently, the city. 
Hence, for the Mineirão workers, the access to a fixed workspace at the stadium was a source of steady income that allowed them to build their houses, to build their lives, and to make a living. Vilma, who became a stallholder herself as an adult after working in the stadium as a child, has narrated how she decided to start selling the tropeiro $^{20}$ dish once she found out that Mineirão was about to close. She recalled seeking help from another worker, who taught her how to prepare the dish. Although it was not possible to find out who started selling tropeiro at Mineirão and from when, the dish became intrinsically connected with the stallholders and the stadium. They were a part of the cultural experience of going to the stadium: to arrive early and spend some time at the stalls, drinking and eating the famous tropeirão do Mineirão. In their narratives, the stallholders were keen to discuss their particular ways of preparing the recipe and its origins. They also often associate the tropeiro with their material possessions. That is the case of Vilma, who told the story of how she managed to build her house, while showing pictures of the construction in different moments of time.

This was all a ravine, look, there was no sewerage, there was nothing. Look how my house used to be without the ceiling. All of this I solved while working at Mineirão. (...) But, then, I got this shack the way it was... because when I realised that the Mineirão was going to close, my dear, I said: "What? Where am I going to find the money? Where am I going to work to find the money and build the ceiling (bater laje) for a house this size?" Then, thank God, Lourdinha taught me how to make tropeiro. I have learned how to make the tropeiro and before the Mineirão closed I still managed to save some money and buy a sofa set because I did not own even a sofa. (Interview with Vilma, Mineirão stallholder - 04/08/15)

For Vilma and Lucia, having access to public space has engendered both their capacities to access the rights to work and to have a house. A similar situation was narrated by several other workers that used to occupy the area. Through time, they have used the income from their sales to build their lives, while also transforming that space into a meaningful place for themselves and for

\footnotetext{
${ }^{20}$ Feijão tropeiro is a typical Brazilian dish, associated mainly with Minas Gerais (although also popular in São Paulo and Goiás). It is made with beans, bacon, sausage, collard greens, eggs and manioc flour. At the stadium, the dish was served with rice and an egg on top.
} 
those attending football matches. In my conversation with these workers, they have told me stories about their own conviviality, the feeling of community and solidarity between them, their hardships, but also their relationship with the supporters. Although they were informal from a strictly legal point of view, their presence was associated with that space, and negotiated constantly with multiple state agents. They felt like they belonged and it was through their work in that space that they were also able to find their place in the city.

\subsection{The multiple effects of workspace displacement}

In Brazil, the 1988 Constitution extended political, civil and social rights to all. Nonetheless, many are still excluded from the exercise and access to those rights. In another word, formal - having rights in theory - and substantive citizenship - actually having access to those rights - are not coincident categories. In the case of the stallholders, accessing the rights to house and to work are mediated by their capacity to claim workspace. In this context, the displacement from the stadium has affected the stallholders' lives negatively in several dimensions, as illustrated by the case of Aparecida, introduced in the outset of this paper. Her story further reveals the connection between living and working informally. The displacement she suffered from her workspace has influenced negatively her capacity to afford rent, forcing her to move from her house to a shack, where she is again facing potential displacement. The possibility of being evicted from her current home made her reflect about the differences between her living and working situation. The same way she is entitled to compensation because her home is being taken from her, she believes a similar principle should apply to her working condition, as the time spent working in the Mineirão stadium with the other stallholders created the sense that the space was like home to her. Nonetheless, the city (and federal) legislation only (partially) recognises her rights as an informal dweller, but not as an informal worker.

The institutional apparatus that underpins Aparecida's rights as an informal dweller are inscribed in the Municipal Housing Policy (PMH), the same local legislation that has guaranteed partial compensation for the Vila UFMG residents. This policy was the result of the struggles 
emerging from the autoconstructed peripheries, where the insurgent citizens have claimed the "rights to the city" they had built (Caldeira, 2016; Holston, 2008). Those rights have also been incorporated in the City Statute, a federal legislation which is internationally celebrated for recognising the "right to the city" as a collective right (Fernandes, 2007a). Despite its importance in meeting the demands of the urban reform agenda, the concept of "urban space production" that has been incorporated in the City Statute does not account for the contributions of other agents, such as informal workers, in the making of the city.

The story of the Mineirão stallholders challenges such narrow understanding of urban space production, showing how their activity in the stadium has shaped that space, while also engendering their capacity to belong to the city. Those workers' attachment to that place can be perceived through their constant association with the stadium and their homes. During interviews, they told histories about how they had "raised their children" on that space, how their houses were all built through their work there, and how the displacement from the stadium affected their family lives in multiple ways. After the modernisation of the stadium, in the absence of previous legal-institutional developments that could legitimise their rights to relocation, the disarticulation of the space also meant the loss of the arrangements that guaranteed their access to workspace.

Since their eviction, the Mineirão stallholders have been fighting for the right to resume their activities. On July 2015, the stallholders' association (ABAEM) was still very active even though five years had passed since their displacement from the stadium. The ABAEM members met regularly at the Mineirinho, a sports arena located across the street from the Mineirão, where the association has a small office. The main purpose of those gatherings was to plan their next steps in the fight to return to the stadium but they also functioned as a place of encounter where they could revisit their lost community. During meetings, the ABAEM workers would constantly talk about the past, narrating stories from the old Mineirão, where they belonged. One can thus conclude that, in addition to impairing the workers' capacity to make a living, the displacement suffered has 
also engendered the same feelings of grieving and mourning described in the literature about home displacement. Atkinson (2015, p.382) for instance argues that displacement from ones' neighbourhoods often disrupts peoples' social networks, while generating “major practical problems, emotionally charged feelings of loss and a sense of trauma among those $(\cdots)$ affected." Investigating the consequences of gentrification, he further argues that the process often "brought feelings of isolation and alienation as well as a deeper sense of nostalgia for changing social relations and lost connections" (ibid, p.382).

Although the stallholders' activity was regulated and legitimised by different levels of government throughout time, in Brazil - as in many other countries - the right of street vendors to workspace is not recognised in the legislation. Commenting on the stallholders' situation, Juliana - the public defender in charge of the case - talks about the relationship between informality and rights.

Then I think that, in this aspect, the fact that the regional state has treated this so informally, that was prejudicial. Because afterwards, you see how life works, right? Afterwards, you try to negotiate through a dialogue. But the right is on which side? Where does it go to? To the justice system. And what does the judiciary require? Documents, facts, data. And they are informal. You see what I mean? And that is why I believe that... in this point, they have lost. (Interview with Juliana, public defender $-21 / 09 / 15)$

In their case, therefore, the spatial restructuring caused by the World Cup represented the loss of the stallholders' legitimacy, which emanated from the social arrangements embedded in that particular place, no longer existent. Displacement emerges as the loss of place, not only as a meaningful space, but also as the product of "socially, politically and economically interconnected interactions among people, institutions and systems" (Pierce et al., 2011, p.59). That place, transformed by the stallholders through their activity, no longer exists and the workers are told that they do not belong in the new stadium anymore. 


\section{Concluding discussions}

Debates about urban informality are back on the international agenda, following claims of the arrival of an "urban age" (Brenner and Schmid 2014; Burdett and Sudjic 2007) and the "planet of slums" (Davis 2006). In the past, informality has been mainly understood as the absence of the state or its failure, a product of disjointed modernisation (Fox 2014). Recent developments in postcolonial urban studies have sought to challenge such binary views, arguing instead for an understanding of informality as a mode of urban governance reproduced by the state (Roy 2005; Watson 2009; Yiftachel 2009). This paper has sought to contribute to this debate, particularly to the recent attempts to challenge vertical accounts of state/society relations (te Lintelo 2017), showing instead that (in)formality arises as the result of many state and non-state agents in negotiation (Hackenbroch, 2011; Schindler, 2014). I propose then a relational approach (Massey 2005) to urban informality that incorporates an account of the state as a processual and porous entity (Mitchell 2006; Painter 2006). Building on this framework, I sought to make two main points. Firstly, I have used the case of Brazil to show how not only the state affects the (re)production of informality but also how informal spaces also affect the state. Secondly, I foreground the connection between distinct informal practices, revealing how the urban poor struggle for rights is depended upon their capacity to access urban space for multiple purposes.

The main aim of the paper was then to compare the displacement suffered by informal workers and informal residents. Two main conclusions were reached. Firstly, although both the right to work and to have a house are recognised by the Brazilian Constitution, claims upon space based on those constitutional rights hold differing levels of legitimacy. Informal housing is thus treated differently from informal street vending by the state. In the Brazilian context, the historic struggle of the social movements for housing has engendered the creation of institutions that can manage the displacement of informal settlements with the guarantee of minimum rights. On the 
other hand, informal occupation for work purposes, despite being a widespread practice, does not hold the same institutional support. The result, therefore, is that informal workers are often unable to claim their rights to workspace. Secondly, both practices - living and working informally - are connected through the survival strategies of the urban poor. That has been shown by focusing on the lives of informal workers, revealing how the rights to housing and work are mediated by their ability to access urban space, which become endangered by the displacement from their workspace. My argument is based on a relational approach to urban informality that foregrounds the ways in which workspaces and the home are built in relation to one-another (Kudva 2009; Lago 2011). In this context, accessing urban space for labour can be vital for those struggling for a place in the city, but unlike the right to housing, discussions about the right to work have being disassociated from space.

The advancements of the urban reform in Brazil have been sustained by a theoretical framework that conflated the "right to the city" with the right to housing and participatory urban planning. Underpinning this framework is the idea that urban space is produced either through the construction of houses or through planning. Despite the centrality of accessing workspace for the livelihood of marginalised urban populations, the right of informal workers to access urban space has been mostly ignored in Brazil as well as around the globe (Brown 2015; Schindler 2014). I argue that informal vendors, much like the insurgent citizens arising from the autoconstructed peripheries (Holston 2008), are also building the city which is also rightfully theirs. Firstly, they make place by attaching meaning to space and forming community ties to each other in that place through their work. Secondly, access to workspace is fundamental to urban livelihoods, allowing marginalised groups to belong to the city. Thirdly, income from informal labour is often employed in the autoconstruction process of the home. Considering the Mineirão stallholders, a fourth aspect can be added. In their case, place also embeds the socio-political arrangements that allow the workers to claim access to workspace in non-confrontational ways. 
The findings have shown that displacement from the home and from the workspace have similar consequences. Firstly, displacement causes the sentiment of frustration associated with the loss of the home and the community (Atkinson, 2015; Davidson, 2009; Fried, 2000). Secondly, the disarrangement of social networks often impact negatively in the life strategies of marginalised citizens (Yntiso, 2008). Those features reveal the need to think about the articulations between the rights to work, to dwell and their connections to urban space.

Debates about work informality have so far remained disassociated from spatial considerations and the literature on displacement is mostly concerned with home evictions. Although the latter is a traumatic experience that engenders a variety of negative consequences in need of careful scrutiny, this paper has argued that displacement from workspaces can generate similar consequences. Around the world, marginalised populations depend on informal employment to survive. Accessing workspace can be thus fundamental to the urban poor. Moreover, informal spaces are normally connected and urban populations are dependent on incomes from informal occupations to build houses and pay for living costs. In order to understand the everyday experiences of the urban poor in the city, more attention to such connections by researchers is necessary. 


\section{References}

Agamben, Giorgio. 1998. Homo Sacer: Sovereign Power and Bare Life. Stanford University Press.

Bayat, Asef. 2004. "Globalization and the Politics of the Informals in the Global South." Urban Informality: Transnational Perspectives from the Middle East, Latin America and South Asia, Lexington Books, Lanham.

Bedê, Mônica Maria Cadaval. 2005. "Trajetória Da Formulação E Implantação Da Política Habitacional de Belo Horizonte Na Gestão Da Frente BH Popular 1993-1996." ["The Trajectory of the Formulation and Implementation of Belo Horizonte's Housing Policy in the BH Popular Front administration 1993-1996."] Unpublished Masters Dissertation, UFMG, Belo Horizonte.

Bhowmik, Sharit. 2012. Street Vendors in the Global Urban Economy. Taylor \& Francis. https://books.google.co.uk/books?hl=en\&lr=\&id=HvggOfljiWEC\&oi=fnd\&pg=PP2\&dq=Str eet+vendors+in+the+global+urban+economy\&ots=9m0uFC0ta6\&sig=Uubcpi3Z6RZIMLKO0jEeCFj1NA.

Boamah, Emmanuel Frimpong, and Margath Walker. 2017. "Legal Pluralism, Land Tenure and the Production of 'nomotropic Urban Spaces' in Post-Colonial Accra, Ghana." In Geography Research Forum, 36:86-109.

Brenner, Neil, and Christian Schmid. 2014. "The 'urban Age'in Question." International Journal of Urban and Regional Research 38 (3): 731-755.

Brown, Alison. 2015. "Claiming the Streets: Property Rights and Legal Empowerment in the Urban Informal Economy." World Development 76: 238-248.

Burdett, Ricky, and Deyan Sudjic. 2007. The Endless City: An Authoritative and Visually Rich Survey of the Contemporary City. Phaidon Press. http://eprints.lse.ac.uk/59099/.

Caldeira, Teresa P. R. 2016. "Peripheral Urbanization: Autoconstruction, Transversal Logics, and Politics in Cities of the Global South." Environment and Planning D: Society and Space, 263775816658479.

Caldeira, Teresa P. R., and James Holston. 2015. "Participatory Urban Planning in Brazil.” Urban Studies 52 (11): 2001-2017.

Chiodelli, Francesco. 2016. "International Housing Policy for the Urban Poor and the Informal City in the Global South: A Non-Diachronic Review." Journal of International Development 28 (5): 788-807.

Costa, Heloisa Soares de Moura Costa. 1989. "A Reforma Urbana E a Busca Da Cidadania.” ["Urban Reform and the Quest for Citizenship."] Indicador, Belo Horizonte: Assembléia Legislativa Do Estado de Minas Gerais, v. 6, N. 27, P. 889-893, Out./Dez. 1988. https://dspace.almg.gov.br/bitstream/11037/2543/3/2543.pdf.

Crossa, Veronica. 2009. "Resisting the Entrepreneurial City: Street Vendors' Struggle in Mexico City's Historic Center." International Journal of Urban and Regional Research 33 (1): 4363.

. 2016. "Reading for Difference on the Street: De-Homogenising Street Vending in Mexico City." Urban Studies 53 (2): 287-301.

Davis, Mike. 2006. Planet of Slums. London: Verso. https://ernstchan.com/b/src/1470180098-070297.pdf.

Fernandes, Edésio. 1995. Law and Urban Change in Brazil. Avebury. 2007. "Constructing the Right to the City'in Brazil." Social \& Legal Studies 16 (2): 201-219. 2012. "Do Código Civil Ao Estatuto Da Cidade: Algumas Notas Sobre a Trajetória Do Direito Urbanístico No Brasil." ["From the Civil Code to the City Statute: Some Notes on the Trajectory of Urban Law in Brazil."] Revista Jurídica 5 (5). http://www.uniaraxa.edu.br/ojs/index.php/juridica/article/viewFile/136/127.

Fischer, Brodwyn, Bryan McCann, and Javier Auyero. 2014. Cities from Scratch: Poverty and Informality in Urban Latin America. Duke University Press.

Fox, Sean. 2014. "The Political Economy of Slums: Theory and Evidence from Sub-Saharan Africa." World Development 54: 191-203. 
Gaffney, Christopher. 2010. "Mega-Events and Socio-Spatial Dynamics in Rio de Janeiro, 19192016." Journal of Latin American Geography 9 (1): 7-29.

Ghertner, D. Asher. 2015. Rule by Aesthetics: World-Class City Making in Delhi. Oxford University Press. https://books.google.co.uk/books?hl=en\&lr=\&id=FjtICgAAQBAJ\&oi=fnd\&pg=PP1\&dq=rul e+by+aesthetics\&ots=SZIHsNtyHg\&sig=K2P3axKWWrOfBJpFMKhz3yRyUYY.

Hackenbroch, Kirsten. 2011. "Urban Informality and Negotiated Space: Negotiations of Access to Public Space in Dhaka, Bangladesh.” disP-The Planning Review 47 (187): 59-69.

Holston, James. 1991. “Autoconstruction in Working-Class Brazil." Cultural Anthropology 6 (4): $447-465$.

2008. Insurgent Citizenship: Disjunctions of Democracy and Modernity in Brazil. Princeton University Press.

https://books.google.co.uk/books?hl=en\&lr=\&id=SZVU_sj1JREC\&oi=fnd\&pg=PR11\&dq=I nsurgent+citizenship:+Disjunctions+of+democracy+and+modernity+in+Brazil.\&ots=WoLSy C8z--\&sig=mV35CsCDxTbXxFkmozXnRK3iW9M.

- 2009. "Insurgent Citizenship in an Era of Global Urban Peripheries." City \& Society 21 (2): 245-267.

Itikawa, Luciana Fukimoto. 2016. "Women on the Periphery of Urbanism: Subordinate Informality, Disarticulated Autonomy and Resistance in São Paulo, Mumbai and Durban." Revista Brasileira de Estudos Urbanos E Regionais 18 (1): 51-70.

Kudva, Neema. 2009. "The Everyday and the Episodic: The Spatial and Political Impacts of Urban Informality." Environment and Planning A 41 (7): 1614-1628.

Lago, L. C. 2011. "Trabalho E Moradia Na Periferia de Uma Grande Metrópole: Para Uma Política Urbana Economicamente Orientada." ["Work And Dwelling In The Periphery Of A Large Metropolis: Towards An Economically Oriented Urban Policy."] Território E Planejamento, 195-216.

Lefebvre, Henri. 1968. "Le Droit À La Ville.” In . Paris: Anthopos.

Lintelo, Dolf JH te. 2017. "Enrolling a Goddess for Delhi's Street Vendors: The Micro-Politics of Policy Implementation Shaping Urban (in) Formality." Geoforum 84: 77-87.

Maricato, Erminia. 1979. A Produção Capitalista Da Casa (E Da Cidade) No Brasil Industrial. [The Capitalist Production Of House (And The City) In Industrial Brazil] Vol. 1. Editora AlfaOmega.

Maricato, Ermínia. 1988. “The Urban Reform Movement in Brazil.” International Journal of Urban and Regional Research 12 (1): 137-138.

Maricato, Ermínia, and João Sette Whitaker Ferreira. 2002. “Operação Urbana Consorciada:

Diversificação Urbanística Participativa Ou Aprofundamento Da Desigualdade.”

["Consortium Urban Operation: Participatory Urban Diversification or Inequality Deepening."] Estatuto Da Cidade E Reforma Urbana, Novas Perspectivas Para as Cidades Brasileiras. [City Statute and Urban Reform, New Perspectives for Brazilian Cities] Porto Alegre: Sergio Fabris Editora.

http://www6.fau.usp.br/depprojeto/labhab/biblioteca/textos/ferreira_operacoesurbanasconsorc .pdf.

Massey, Doreen. 2005. For Space. Thousand Oaks, California: Sage.

Mitchell, Katharyne. 2006. "Geographies of Identity: The New Exceptionalism." Progress in Human Geography 30 (1): 95-106.

Mitchell, Timothy. 2006. "Society, Economy, and the State Effect." The Anthropology of the State: A Reader, 169-186.

Molotch, Harvey. 1976. "The City as a Growth Machine: Toward a Political Economy of Place." American Journal of Sociology 82 (2): 309-332.

Nascimento, Denise Morado. 2016. "Accessing the Urban Commons Through the Mediation of Information: The Eliana Silva Occupation, Belo Horizonte, Brazil." International Journal of Urban and Regional Research. http://onlinelibrary.wiley.com/doi/10.1111/1468-

2427.12415/full. 
Oliveira, Francisco de. 2003. "Crítica À Razão Dualista." [A Critique to the dualistic reason]. Crítica À Razão Dualista/O Ornitorrinco. São Paulo: Boitempo Editorial.

Organisation for Economic Co-operation and Development (OECD). 2009. "Overview: Data on Informal Employment and Self-Employment.” In Is Informal Normal? Towards More and Better Jobs in Developing Countries. Paris: OECD.

Painter, Joe. 2006. "Prosaic Geographies of Stateness." Political Geography 25 (7): 752-774.

Robinson, Jennifer. 2006. Ordinary Cities: Between Modernity and Development. Vol. 4. Psychology Press.

https://books.google.co.uk/books?hl=en\&lr=\&id=WQ3jmCZrObMC\&oi=fnd\&pg=PR7\&dq= ordinary+cities+jennifer+robinson\&ots=hHR6yskcXC\&sig=x6kCqpGZaZ_q4xHMklNaZm WCCl4.

Rolnik, Raquel. 2013. "Ten Years of the City Statute in Brazil: From the Struggle for Urban Reform to the World Cup Cities." International Journal of Urban Sustainable Development 5 (1): 54 64.

Rosa, Elisabetta. 2017. "Rules, Transgressions and Nomotropism: The Complex Relationship between Planning and Italian Abusivismo." In Geography Research Forum, 36:110-126.

Roy, Ananya. 2005. "Urban Informality: Toward an Epistemology of Planning." Journal of the American Planning Association 71 (2): 147-158.

Roy, Ananya, and Nezar AlSayyad. 2004. Urban Informality: Transnational Perspectives from the Middle East, Latin America, and South Asia. Lexington Books.

https://books.google.co.uk/books?hl=en\&lr=\&id=RxAGdfEiIXEC\&oi=fnd\&pg=PR7\&dq=Ur ban+Informality:+Transnational+Perspectives+from+the+Middle+East,+Latin+America,+and +South+Asia.\&ots=t7Y8Z363EK\&sig=X5Ry9dmeO19qLbv35FvQBIJd1VU.

Sánchez, Fernanda, and Anne-Marie Broudehoux. 2013. "Mega-Events and Urban Regeneration in Rio de Janeiro: Planning in a State of Emergency." International Journal of Urban Sustainable Development 5 (2): 132-153.

Schindler, Seth. 2014. "Producing and Contesting the Formal/Informal Divide: Regulating Street Hawking in Delhi, India." Urban Studies 51 (12): 2596-2612.

. 2016. "Beyond a State-Centric Approach to Urban Informality: Interactions between Delhi's Middle Class and the Informal Service Sector." Current Sociology, 11392116657296.

Shin, Hyun Bang. 2012. "Unequal Cities of Spectacle and Mega-Events in China." City 16 (6): 728744.

Shin, Hyun Bang, and Bingqin Li. 2013. "Whose Games? The Costs of Being 'Olympic Citizens' in Beijing." Environment and Urbanization, 956247813501139.

Soja, Edward W. 1998. "Thirdspace: Journeys to Los Angeles and Other Real-and-Imagined Places." Capital \& Class 22 (1): 137-139.

Sousa Santos, Boaventura de, and Flavia Carlet. 2009. "The Movement of Landless Rural Workers in Brazil and Their Struggles for Access to Law and Justice." Marginalized Communities and Access to Justice, 60.

Telles, Vera da Silva. 2010. "Nas Dobras Do Legal E Do Ilegal: Ilegalismos E Jogos de Poder Nas Tramas Da Cidade." [In The Folds Of Legal And Illegal: Illegalisms And Power Games In The Webs Of The City] Dilemas: Revista de Estudos de Conflito E Controle 2 (5-6): 97-126.

Varley, Ann. 2013. "Postcolonialising Informality?" Environment and Planning D: Society and Space 31 (1): 4-22.

Watson, Vanessa. 2009. "Seeing from the South: Refocusing Urban Planning on the Globe's Central Urban Issues." Urban Studies 46 (11): 2259-2275. 